\title{
Runoff and Sediment Yield Modeling of Meki River Watershed Using SWAT Model in Rift Valley Lakes Basin, Ethiopia
}

\author{
Aman Bunta ${ }^{1, *}$, Brook Abate ${ }^{2}$ \\ ${ }^{1}$ Hydraulic and Water Resources Engineering, Wollega Institute of Technology, Wollega University, Nekemte, Ethiopia \\ ${ }^{2}$ Civil Engineering, Addis Ababa Science and Technology University, Addis Ababa, Ethiopia
}

Email address:

amanbunta036@gmail.com (A. Bunta), brook.abate@aastu.edu.et (B. Abate)

${ }^{*}$ Corresponding author

To cite this article:

Aman Bunta, Brook Abate. Runoff and Sediment Yield Modeling of Meki River Watershed Using SWAT Model in Rift Valley Lakes Basin, Ethiopia. American Journal of Civil Engineering. Vol. 9, No. 5, 2021, pp. 155-166. doi: 10.11648/j.ajce.20210905.12

Received: September 21, 2021; Accepted: October 12, 2021; Published: October 28, 2021

\begin{abstract}
Loss of soil fertility in agricultural lands and sedimentation in lakes of central rift valley of Ethiopia are major watershed problem threatening the agro economy in the area. To develop effective erosion control plans through implementing appropriate soil conservation practices, runoff and sediment yield in Meki watershed was estimated and analyzed using the SWAT model. The model showed the simulated mean annual surface runoff was $114.03 \mathrm{~mm}$ and the mean annual streamflow was $9.41 \mathrm{~m}^{3} / \mathrm{s}$. Similarly, mean annual sediment load of $13.12 \mathrm{t} / \mathrm{ha}$ enters to Lake Ziway. The model was calibrated and validated on daily and monthly time step for flow and on monthly time step for sediment yield. The results of Nash Sutcliff Efficiency of 0.71 on daily and 0.89 on monthly time steps for streamflow and its value of 0.80 on monthly time step for sediment yield during calibration showed that there is a good match between measured and simulated data for both variables on daily basis and very good match on monthly basis. The potential erosion source areas were identified. Likewise, $51.34 \%$ of the watershed area was found to be potential erosion sources and priorized for erosion control plans.
\end{abstract}

Keywords: Meki Watershed, Runoff, Sediment Yield, SWAT, SWAT-CUP

\section{Introduction}

\subsection{General Background}

Soil erosion is a major global soil degradation threat to land, freshwater, and oceans [1]. In countries like Ethiopia whose economy is highly based on agriculture, soil degradation (the loss of nutrient-rich top soil) leads to loss of soil quality and hence reduce crop yield. The severity of soil erosion is caused due to the both of natural effects such as aggressive climate, steep topography and erodible soil type and human activities such as land clearing for agriculture and particularly overgrazing, firewood stripping has resulted in a rapid acceleration of soil erosion [2]. Sadly, this condition is being escalated in Meki River watershed in particular and rift valley lakes basin in general. Soil erosion and nutrient losses are therefore recognized to be severe threats to the national economy of Ethiopia and leads to food insecurity [3].
In order to tackle the problem of soil erosion, effective watershed management at sub-basin level is crucial. Most recently, watershed management is an approach followed by the government of Ethiopia to reduce soil erosion in particular and to reverse land degradation in general (4). Reliable predictions of the quantity and rate of runoff from land surface into streams, rivers and water bodies [5] and assessing spatial and temporal variability of the magnitude and intensity of sediment yield [6] are needed to support decision makers in developing watershed management plans for better soil and water conservation measures.

Therefore, this study is conducted to estimate runoff and sediment yield, to determine the spatial variability of sediment yield and to identify the most erosion prone subwatershed areas in Meki river watershed.

\subsection{Statement of the Problem}

Over the last two decades; the existing land and water 
resources system of central rift valley of Ethiopia was adversely affected by the rapid growth of population, deforestation and surface erosion. The Meki watershed is one of the sub watersheds located in a such area under series pressure of unsustainable socio-economic activities and hence, under danger of degradation. This is due to sharply increasing demands for farmlands associated with dramatically increasing population in order to withstand the usual chronic famine in the region. The enormous expansion of agricultural land, especially on the higher and steeper parts of the watershed has made the topmost soil more vulnerable to erosion.

As the population of Ethiopia primarily depends on agriculture to support their lives, the loss of fertile soil would result in less production. This problem has been an acute food insecurity in the region. The loss of soil is therefore can be necessarily defined as the loss of food in country like Ethiopia. Therefore, this research was addressed to model the runoff and sediment yield to contribute a lot on the way towards tackling the problem.

\subsection{Objectives of the Study}

The main objectives of this study are to predict runoff and sediment yield and to prioritize the erosion prone areas in Meki River watershed in order to support improvement of basin management programs at the sub-basins level.

\section{Materials and Methods}

\subsection{Description of Study Area}

Meki River watershed is one of the northern part tributaries of Ethiopian Rift Valley Lakes basin. The river takes its rise from upstream of Gurage chained mountains in Southern Nation Nationalities and peoples of Ethiopian Regional State and ends emptying its flow to Lake Ziway in Dugda district of Oromia regional state after traversing for a length of $100 \mathrm{~km}$. It is located between $7^{\circ} 50^{\prime} 00^{\prime \prime} \mathrm{N}$ to $8^{\circ} 28^{\prime} 00^{\prime \prime} \mathrm{N}$ latitudes and $38^{\circ} 14^{\prime} 00^{\prime \prime} \mathrm{E}$ to $38^{\circ} 54^{\prime} 00^{\prime \prime} \mathrm{E}$ longitudes (figure 1). The total catchment area upstream of the gauging station near Meki town is estimated to be $2073.51 \mathrm{Km}^{2}$.

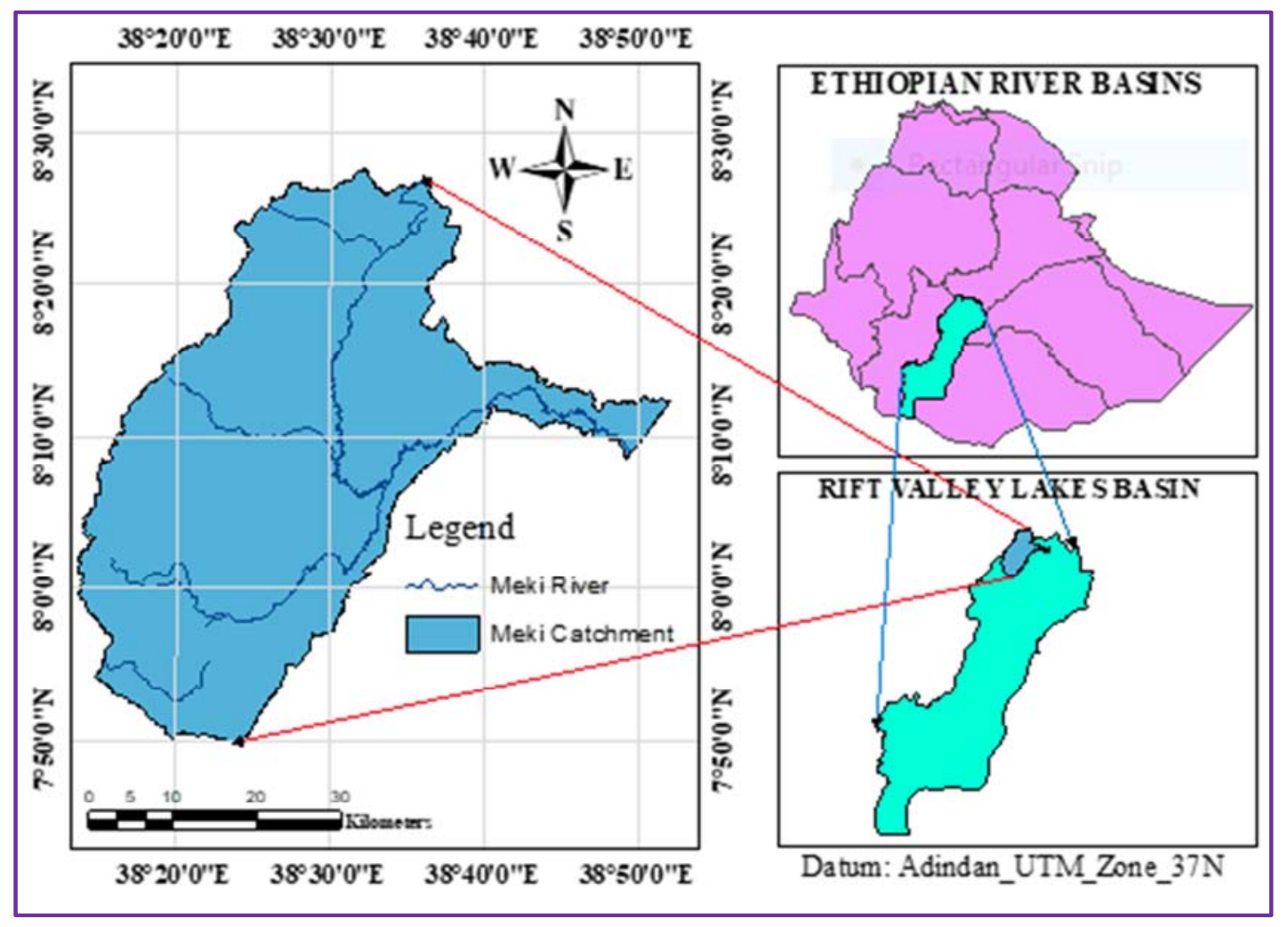

Figure 1. Location of study area.

\subsection{Tools and Datasets Used}

In order to achieve the intended goal of the study, the main tools used to prepare input data for SWAT model are Arc GIS 10.4.1 software, Arc SWAT 2012 model database, PCSTAT and DEWPOINT. SWAT-CUP model was used to calibrate and validate the model outputs SWAT model to characterize runoff and sediment yield of watershed are: spatial data (Digital Elevation Model, Landuse Landcover and soil), meteorological data and hydrology data.

\subsubsection{Digital Elevation Model}

Digital Elevation Model (DEM) with spatial resolution of $12.5 \mathrm{~m} \times 12.5 \mathrm{~m}$ was downloaded from Image courtesy of the USGS Earth Explorer (https://earthexplorer.usgs.gov/) website as SRTM 1 Arcsecond Global. It was used to delineate the watershed and sub-watersheds as the drainage surfaces, stream network and longest reaches on the basis of elevation. 
Meki River watershed has Minimum elevation of $1631 \mathrm{~m}$, maximum elevation of $3612 \mathrm{~m}$ and mean elevation of $2153.98 \mathrm{~m}$ above mean sea level (figure 2A). Slope classes of the study area (four classes) were also derived from the DEM (figure 2B). The slope classes are required by SWAT model for the sub-basins HRUs generation.

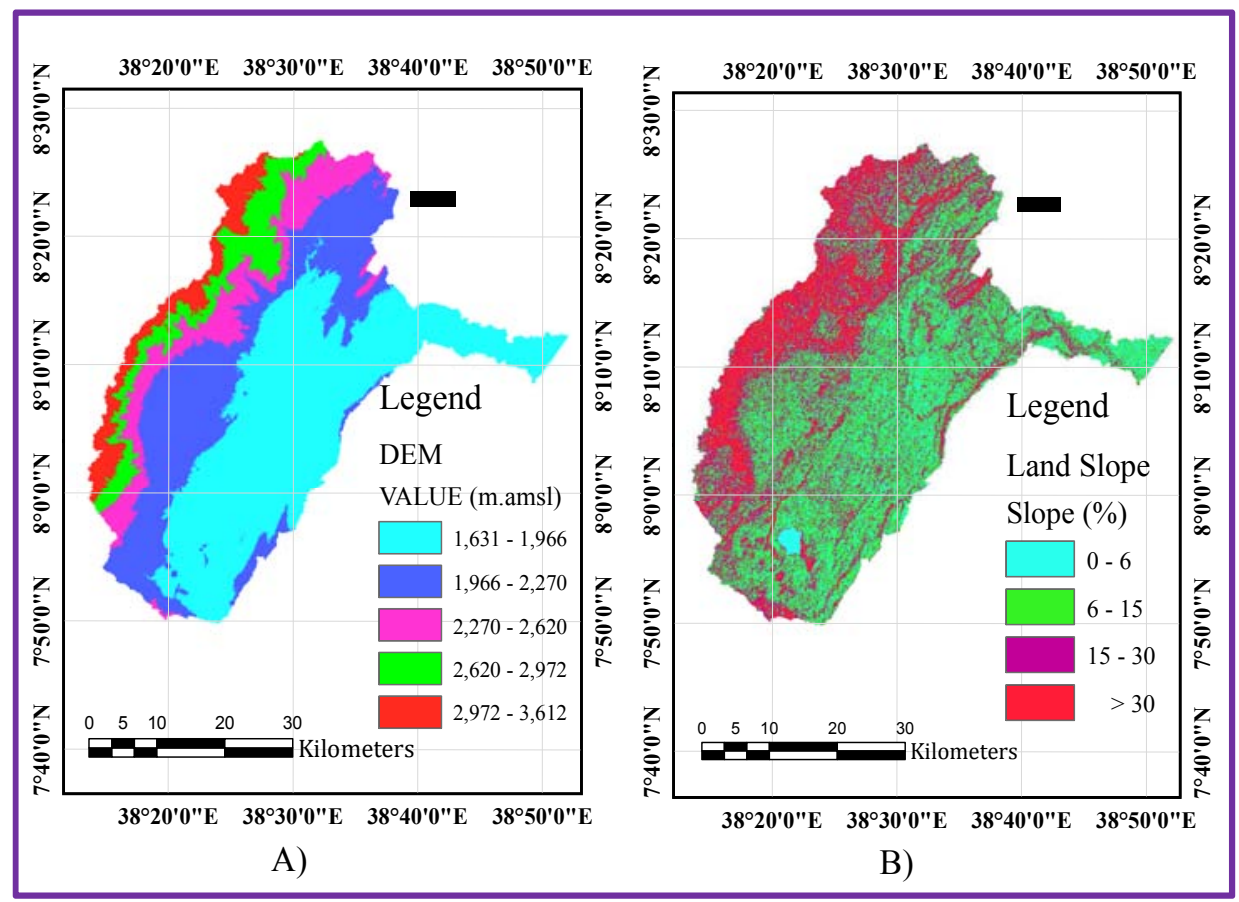

Figure 2. A) DEM, B) Slope classes of Meki watershed.

\subsubsection{LULC and Soil Data}

The Land use and raster soil map of Meki watershed were also collected from Ministry of Water, Irrigation and Energy of Ethiopia. The watershed consists of eight major land use/cover classes (figure 3A). The most dominant one is Agricultural land (89.49\%) followed by grassland $(6.33 \%)$ and Forest Cover $(1.70 \%)$ respectively. There have been also ten major soil groups identified in the study area based on FAO soil classification system (figure 3B). Eutric Cambisols, Eutric Vertisols and Chromic Luvisols are the most dominant soil types and covers about $70.45 \%$ of the total area in combination.

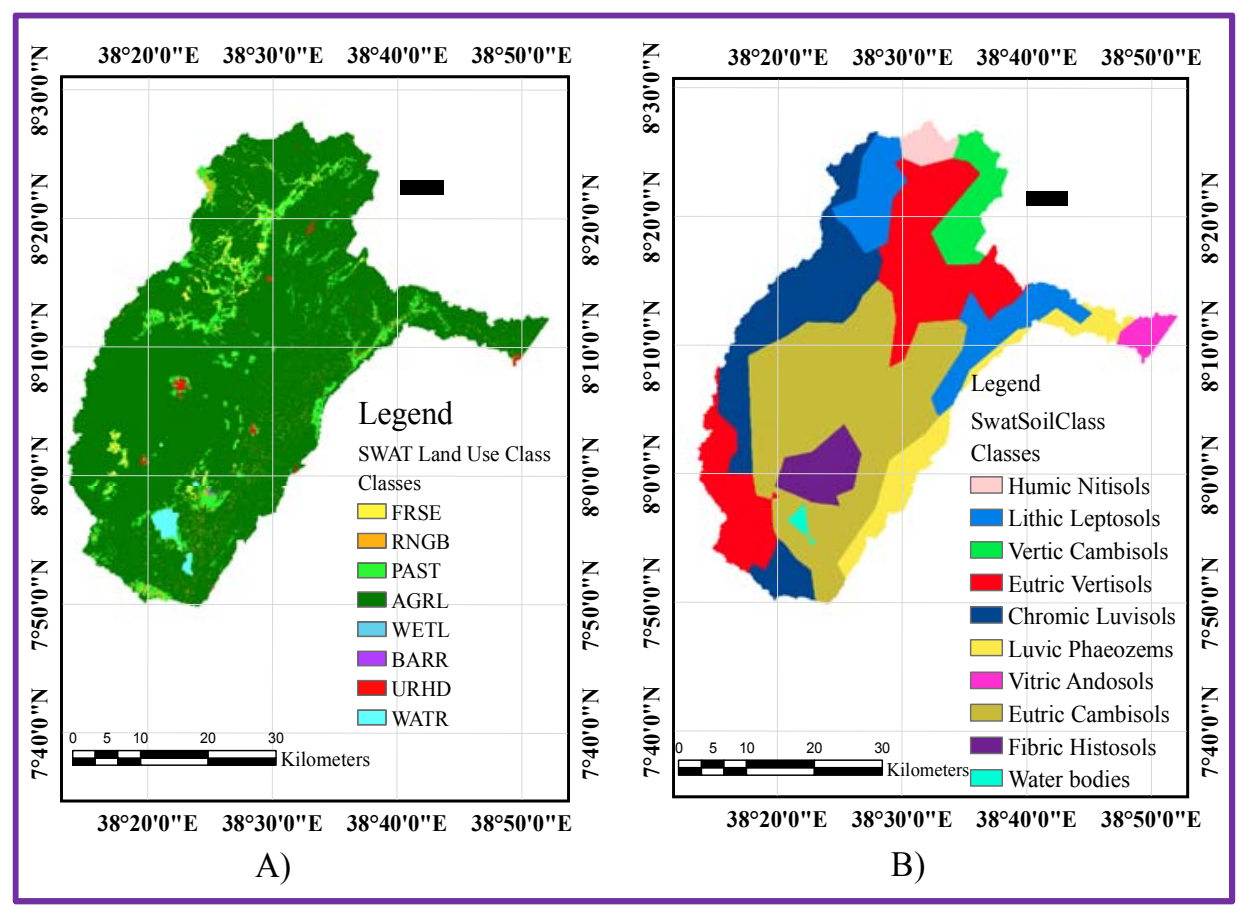

Figure 3. A) LULC, B) Soil classes of Meki watershed. 


\subsubsection{Meteorological Data}

Meteorological variables (rainfall, temperature, solar radiation, wind speed and humidity) of six stations (table 1) for period of (2001-2020) were acquired from the National Meteorological Agency of Ethiopia. Solar radiation, relative humidity, and wind speed data were available only for Bui station. The SWAT weather generator model was used to fill missed values in weather data of relative humidity, wind speed and solar radiation.

Table 1. Details of weather monitoring stations in Meki Watershed.

\begin{tabular}{lllll}
\hline \multirow{2}{*}{ Name } & \multirow{2}{*}{ Altitude $(\mathbf{m})$} & \multirow{2}{*}{ Class } & \multicolumn{2}{c}{ Location (decimal degree) } \\
\cline { 4 - 5 } & & Latitude & Longitude \\
\hline Bui & 2054 & I & 8.33083 & 38.55444 \\
Butajira & 2000 & III & 8.15000 & 38.36667 \\
Ejersalele & 2057 & IV & 8.24320 & 38.68600 \\
Koshe & 1878 & IV & 8.00650 & 38.52530 \\
Tora & 2001 & IV & 7.85550 & 38.42067 \\
Meki & 1662 & IV & 8.15100 & 38.81700 \\
\hline
\end{tabular}

\subsubsection{Hydrological Data}

Streamflow and suspended sediment data at the outlet of the watershed near Meki town were collected from the Ministry of Water, Irrigation and Energy (MoWIE) of Ethiopia for period of 2001 to 2014. Due to the lack of continuously recorded suspended sediment data, there is a need to develop sediment rating curve by using the measured sediment records as a function of the corresponding streamflow values. The sediment rating curve is a widely applicable technique for estimating the suspended sediment load being transported by a river through signifying a relationship between the stream discharge and sediment concentration or load [7]. Relatively little scatter in field measurements is observed when the sediment load is controlled by the sediment transport capacity. This is due to the fact that the bed material load directly depends on discharge. In such cases, variations in sediment rating curves are due to variability in water temperature, stream slope, bed sediment size, particle size distribution, and measurement errors.

For capacity limited sediment transport, the general relationship of suspended sediment rating curve often fits a power law of the form:

$$
Q_{s}=a * Q_{w}{ }^{b}
$$

Where $Q_{s}$ is sediment concentration in t/day, $Q_{w}$ is water discharge $\left(\mathrm{m}^{3} / \mathrm{s}\right)$, a and $\mathrm{b}$ are coefficients usually obtained by regression analysis.

However, the measured suspended sediment concentration records collected from the MoWIE was in $\mathrm{mg} / \mathrm{l}$ while, the suspended sediment concentration in the general equation of the rating curve was in t/day. Thus, the measured suspended sediment concentration in $\mathrm{mg} / \mathrm{l}$ were converted into sediment load in $\mathrm{t} /$ day by using the following conversion formula:

$$
S=0.0864 * Q_{w} * \mathrm{C}
$$

where: $\mathrm{S}$ is sediment load in $\mathrm{t} / \mathrm{day}, \mathrm{C}$ is sediment concentration in $\mathrm{mg} / \mathrm{l}$ and 0.0864 is conversion factor.

Linear regression is a very important tool for the statistical analysis of data. In this work the simple linear regression is performed to estimate sediment discharge from stream flow discharge. The simple linear Regression equation is given by the following equation.

$$
y_{i}=b_{o}+m x_{i}
$$

Where; $\mathrm{x}_{\mathrm{i}}$ is the dependent variable in this case sediment discharge, $x_{i}$ is the independent variable (water discharge), $m$ is the slope of the graph and $b_{o}$ is the intercept.

When we convert the above power function into this form of linear Regression equation, the equation will become the following one:

$$
\log Q_{s}=\log a+b \log \left(Q_{w}\right)
$$

In this case $\mathrm{m}=b$ and $b_{o}=\operatorname{loga}$. The regression is performed by estimating the unknown intercept and slope $b_{o}$ and $\mathrm{m}$ from the given data. By analysis of the regression function, values were obtained to be "a" $=37.98$ and "b" = 1.68. From general relationship of suspended sediment rating curve, the relationship of suspended sediment rating for this particular study becomes:

$$
Q_{s}=37.98 * Q_{w}^{1.68}
$$

The relationship is known as the suspended sediment rating curve (figure 4). Using the rating curve equation continuous time step suspended sediment load ( $t$ /day) values were generated from the daily records of stream flow. The results were converted to monthly time steps using pivot table in excel sheet for calibration and validation.

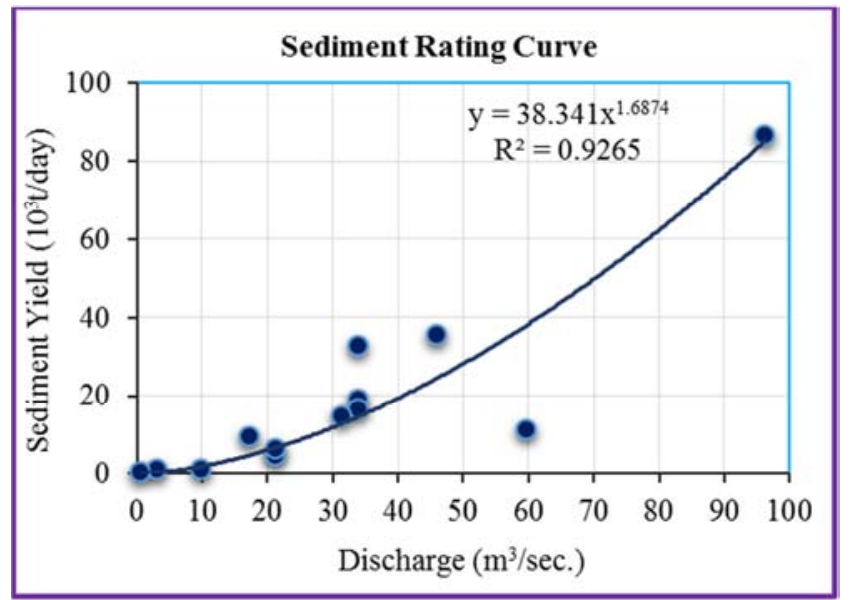

Figure 4. Sediment Rating Curve for Meki Watershed.

\subsection{Rainfall Consistency Test}

The consistency of rainfall records from weather monitoring stations in study area was checked by double mass curve method. To investigate whether there was inconsistency for gauging stations in the catchment, groups of four stations were chosen. The cumulative values of the 
doubtful stations were plotted against the cumulative average group using Microsoft Excel spreadsheet in developing double mass curve (figure 5).

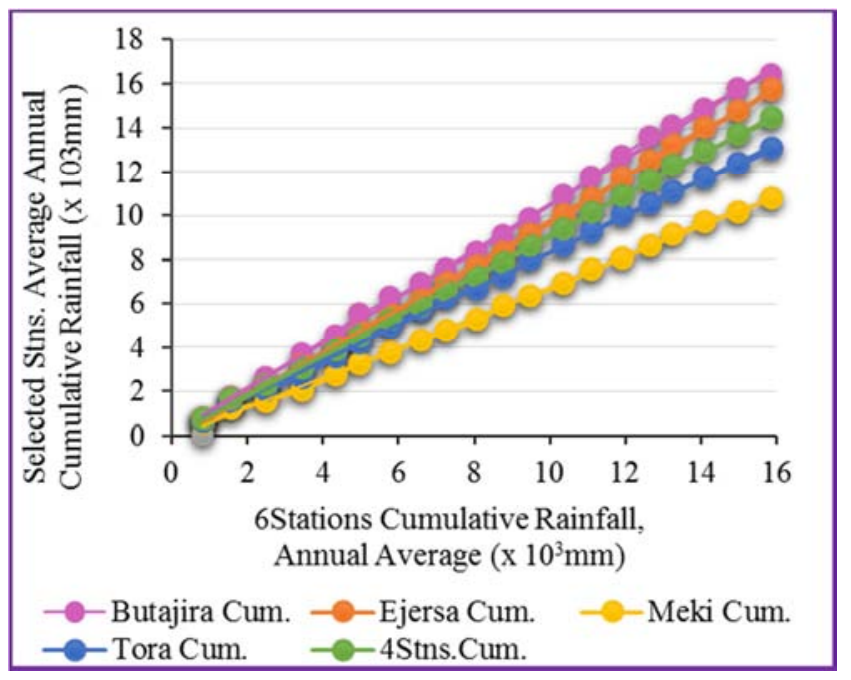

Figure 5. Rainfall consistency check of the selected stations.

\subsection{Description of Arc SWAT}

SWAT is a river basin, or watershed scale model developed to predict the runoff, impact of land management practices on water, sediment, and agricultural chemical yields in large, complex watersheds with varying soils, land use, and management conditions over long periods of time [8]. The program is provided with an interface in ArcGIS for the definition of watershed hydrologic features and storage as well as the organization and manipulation of the related spatial and tabular data [9].

SWAT model divides the catchment into numerous subcatchments, which are further divided into the elementary hydrologic response units (HRUs) of homogenous land use, vegetation and soil characteristics. The total runoff mainly depends on the actual hydrologic condition of each land cover soil type and slope present in the watershed.

\subsection{Hydrological Components of SWAT Model}

SWAT uses two separate components for the simulation of watershed hydrologic cycle: the land phase and routing phase. Hydrological components simulated in the land phase are canopy storage, infiltration and soil moisture redistribution, Evapotranspiration, lateral subsurface flow, surface runoff, ponds and tributary channels return flow. In the land phase of the hydrologic cycle, SWAT simulates the hydrological cycle based on the water balance equation given as:

$$
\mathrm{SW}_{\mathrm{t}}=\mathrm{SW}_{\mathrm{o}}+\sum\left(R_{\text {day }}-Q_{\text {surf }}-E_{a}-W_{\text {seep }}-Q_{\text {gw }}\right)
$$

Where, $\mathrm{SW}_{\mathrm{t}}$ is the final soil water content $(\mathrm{mm}), \mathrm{SW} 0$ is the initial soil water content for day $\mathrm{i}(\mathrm{mm}), \mathrm{t}$ is the days, $\mathrm{R}_{\text {day }}$ is the day precipitation $(\mathrm{mm}), \mathrm{Q}_{\text {surf }}$ is the surface runoff $(\mathrm{mm})$, $\mathrm{E}_{\mathrm{a}}$ is the Evapotranspiration $(\mathrm{mm})$, Wseep is the seepage from the bottom soil layer $(\mathrm{mm})$ and $\mathrm{Q}_{\mathrm{gw}}$ is the groundwater flow on day i (mm).

\subsubsection{Surface Runoff}

SWAT offers two methods to estimate surface runoff: the SCS curve number method [10] and the Green \& Ampt infiltration method [11]. In this study, the SCS curve number method was used to estimate surface runoff from each HRU using daily rainfall. It is based on the area's hydrologic soil group, land use, treatment and hydrologic condition. The SCS curve number equation is (SCS, 1972):

$$
Q_{\text {surf }}=\frac{\left(R_{\text {day }}-I_{a}\right)^{2}}{\left(R_{\text {day }}-I_{a}+S\right)}
$$

Where $Q_{\text {surf }}$ is the surface runoff, or rainfall excess $\left(\mathrm{mmH}_{2} \mathrm{O}\right), \mathrm{R}_{\text {day }}$ is rainfall depth for the day $\left(\mathrm{mmH}_{2} \mathrm{O}\right), \mathrm{I}_{\mathrm{a}}$ is the initial abstraction loss $\left(\mathrm{mmH}_{2} \mathrm{O}\right)$, and $\mathrm{S}$ is retention parameter $\left(\mathrm{mmH}_{2} \mathrm{O}\right)$. The retention parameter varies spatially due to changes in soils, land use, management and slope and temporally due to changes in soil water content. The retention parameter is defined as:

$$
S=25.4\left(\frac{1000}{C N}-10\right)
$$

Where $\mathrm{CN}$ is the curve number for the day. $\mathrm{CN}$ allows the model to modify the moisture condition of the soil to estimate the surface runoff. The initial abstractions, Ia, is commonly approximated as $0.2 \mathrm{~S}$ and by substituting the term $0.2 \mathrm{~S}$ for Ia, equation (7) becomes:

$$
Q_{\text {surf }}=\frac{\left(R_{\text {day }}-0.2 S\right)^{2}}{\left(R_{\text {day }}-0.8 S\right)}
$$

\subsubsection{Sediment Yield}

The SWAT model uses the MUSLE to compute soil erosion at HRU level. MUSLE is a modified version of the Universal Soil Loss Equation (USLE) developed by [12]. USLE predicts average annual gross erosion as a function of rainfall energy. In MUSLE, the rainfall energy factor is replaced with a runoff factor. This improves the sediment yield prediction, eliminates the need for delivery ratios and allows the equation to be applied to individual storm events. The Modified Universal Soil Loss Equation is:

$$
S e d=11.8 .\left(Q_{s} \cdot q_{p} \cdot A_{h r u}\right)^{0.56} \cdot(\text { K.C.P.LS })_{U S L E} . C F R G
$$

Where Sed is the sediment yield on a given day (metric tons), $Q_{S}$ is the surface runoff volume $\left(\mathrm{mm} \mathrm{H}_{2} \mathrm{O} / \mathrm{ha}\right), q_{p}$ is peak runoff rate $\left(\mathrm{m}^{3} / \mathrm{s}\right), A_{h r u}$ is the area of the HRU (ha), $K$ is USLE soil erodibility factor $\mathrm{C}$ is USLE cover and management factor, $P$ is USLE support practice factor, $L S$ is USLE topographic factor and $C F R G$ is coarse fragment factor.

\subsection{Calibration and Validation of SWAT Model}

The model was calibrated using the Sequential Uncertainty Fitting (SUFI-2) algorithm of SWAT-CUP, an interface that was developed for SWAT [13]. Observed Streamflow and sediment data computed from rating curve for the years 2001 to 2014 were used in model calibration and validation. The first two years (2001 to 2002) of the modeling period were used as 'warm-up' period for the model to generate 
reasonable initial values. Data for the period 2003 to 2009 were used for calibration and the dataset of the years 2010 to 2014 were used for model validation.

\subsection{Model Performance Evaluation}

In this study, the goodness-of-fit between the simulated and measured variables during both calibration and validation periods were evaluated using the graphical and statistical parameters such as Nash Sutcliff Efficiency (NSE), Coefficient of determination $\left(\mathrm{R}^{2}\right)$ and Percent bias (PBIAS).

The NSE determines the relative magnitude of the residual variance compared to the measured data variance. NSE is computed as shown in equation 11:

$$
\mathrm{NSE}=1-\left[\frac{\sum_{i=1}^{n}\left(Q_{o, i}-Q_{S, i}\right)^{2}}{\sum_{i=1}^{n}\left(Q_{o, i}-\bar{Q}_{o}\right)^{2}}\right]
$$

Where $Q_{o, i}$ and $Q_{s, i}$ are the observed and simulated values during model evaluation in respective time steps $i, \bar{Q}_{o}$ is the mean of observed data values during model evaluation and $n$ is the number of observations.

The value of NSE ranges between $-\infty$ and 1 , with $\mathrm{NSE}=1$ being optimum value. Values between 0.6 and 1.0 are viewed as acceptable levels of performance whereas negative values or zero indicate that the mean observed value is a better predictor than the simulated value indicating unacceptable performance.

The $\mathrm{R}^{2}$ describes the proportion of variance in measured data by the model. It indicates the linear relationship between simulated and observed data and $\mathrm{R}^{2}$ is computed as:

$$
R^{2}=\frac{\left[\sum_{i=1}^{n}\left(Q_{o, i}-\bar{Q}_{o}\right)\left(Q_{o, i}-Q_{s, i}\right)\right]^{2}}{\sum_{i=1}^{n}\left(Q_{o, i}-\bar{Q}_{o}\right)^{2}\left(Q_{s, i}-\bar{Q}_{s}\right)^{2}}
$$

Where $\bar{Q}_{s}$ is the mean of simulated data values during model evaluation. $\mathrm{R}^{2}$ ranges from zero to one, with a value of 0 indicating no correlation and a value of 1 representing that the predicted dispersion equals the measured dispersion [14]. Pbias (percentage of deviation) measures the average tendency of the simulated values to be larger or smaller than the observed values. PBIAS is computed as shown in equation 13:

$$
\text { PBIAS }=\left[\frac{\left(\sum_{i=1}^{n}\left(\mathrm{Q}_{\mathrm{o}, \mathrm{i}}-\mathrm{Q}_{\mathrm{s}, \mathrm{i}}\right)\right.}{\sum_{i=1}^{n} \mathrm{Q}_{o, i}}\right] * 100
$$

where PBIAS is the deviation of data being evaluated, expressed as a percentage. The optimum value of PBIAS is 0.0 , with low magnitude values indicating accurate model simulation. Positive values indicate model underestimation bias, and negative values indicate model overestimation bias [15].

\section{Results and Discussion}

\subsection{Sensitivity Analysis}

Global sensitivity analysis was performed to identify, evaluate and rank parameters that have significant impact on model outputs. The rank of sensitive parameters was determined by using $\mathrm{P}$ values and t-state. The smaller the $\mathrm{p}$ value indicates the more sensitive parameter, whereas the larger the p-value point toward the less sensitive for the given watershed [16]. The values close to zero has more significance. The $t$-stat is the coefficient of a parameter divided by its standard error. The larger, in absolute value of t-stat, the more sensitive the parameter. The sensitive parameters for Meki River watershed were identified separately for stream flow and sediment yield (tables 2 and 3). Curve number (CN2) and Average slope length (SLSUBBSN) are the most sensitive parameters respectively for streamflow and sediment calibration.

Table 2. Sensitivity rank of streamflow parameters.

\begin{tabular}{llll}
\hline Parameter Name & t-Stat & P-Value & Rank \\
\hline R_CN2.mgt & -8.37878 & 0.00000 & 1 \\
V_ALPHA_BF.gw & 3.65498 & 0.00033 & 2 \\
V_SLSUBBSN.hru & 3.15177 & 0.00189 & 3 \\
R_SOL_Z(..).sol & 2.24674 & 0.02585 & 4 \\
R_SOL_AWC (..).sol & 1.24403 & 0.21508 & 5 \\
V_ESCO.bsn & -1.10393 & 0.27107 & 6 \\
\hline
\end{tabular}

Table 3. Sensitivity rank of sediments parameters.

\begin{tabular}{llll}
\hline Parameter Name & t-Stat & P-Value & Rank \\
\hline SLSUBBSN.hru & 4.22878 & 0.00004 & 1 \\
SPCON.bsn & -3.62153 & 0.00038 & 2 \\
EROS_EXPO.bsn & -2.80285 & 0.00559 & 3 \\
SPEXP.bsn & -2.53854 & 0.01193 & 4 \\
CH_COV1.rte & 1.96602 & 0.05075 & 5 \\
C_FACTOR.bsn & -1.40611 & 0.16132 & 6 \\
\hline
\end{tabular}

The relationship of flow parameters sensitivity and objective function of the model was presented by dotty plots in SWAT CUP-SUFI2 algorithm. Dotty plots are plots of parameter values vs objective function and, the main purpose of these graphs is to show the distribution of the sampling points of sensitive parameter. For Meki watershed, dotty plots of the first four sensitive parameters are shown as an illustrative example in figure 6 . The $\mathrm{X}$-axis represents ranges of calibration parameters where, the Y-axis is values of objective function (Nash-Sutcliffe Efficiency).

\subsection{Model Calibration and Validation}

\subsubsection{Flow Calibration and Validation}

Flow was the first output variable calibrated on daily and monthly time-steps by utilizing a time series dataset from $1^{\text {st }}$ January of 2003 to $31^{\text {st }}$ December of 2009. The values of selected model parameters were iterated several times within a reasonable range during calibration until satisfactory agreement between observed and simulated streamflow was obtained. During each iteration, priority was given to add and adjust most sensitive model parameters so that acceptable result could be obtained at minimum number of iterations. Thus, the most sensitive parameter which was the runoff curve number $(\mathrm{CN})$ were adjusted within $\pm 20 \%$. from the tabulated curve numbers to reflect the conservation tillage practices and soil residue cover conditions of the watershed. Model validation for flow was done utilizing five years measured flow data of the period from 1st January of 2010 to 31 st December of 2014. The parameters used in calibration and their fitted values are given in table 4 . 


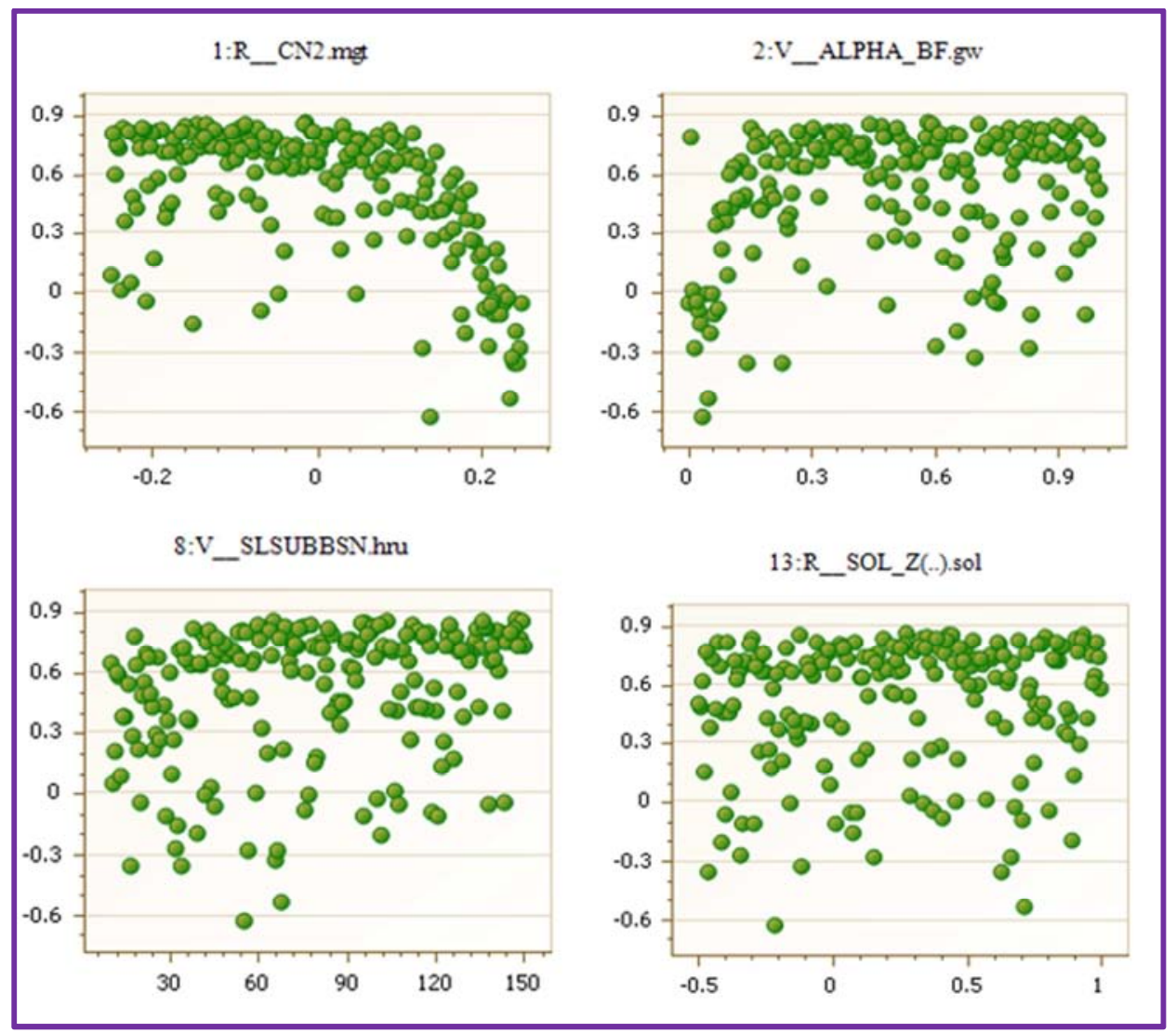

Figure 6. Dot plots showing most sensitive parameters identified during monthly calibration in Sufi-2 in SWAT-CUP.

Table 4. Calibration parameters and their fitted values.

\begin{tabular}{lllll}
\hline Parameter Name & Fitted Value & Minimum value & Maximum value & Method of variation \\
\hline CN2.mgt & 0.07 & -0.20 & 0.20 & Relative \\
ALPHA_BF.gw & 0.18 & 0.00 & 1.00 & Replacement \\
SLSUBBSN.hru & 90.15 & 10.00 & 150.00 & Replacement \\
ESCO.bsn & 0.53 & 0.00 & 1.00 & Replacement \\
SOL_Z(..).sol & 0.17 & -0.50 & 1.00 & Relative \\
OV_N.hru & 25.28 & 0.01 & 30.00 & Replacement \\
SOL_AWC(..).sol & -0.07 & -0.07 & 0.20 & Relative \\
\hline
\end{tabular}

The results of statistical parameters used in model evaluation for daily and monthly streamflow during both calibration and validation periods were depicted in tables 5 and 6 . The result showed that there is a good agreement between measured and simulated daily flows and very good agreement between measured and simulated monthly flows during both calibration and validation. However, model performance during calibration is higher than that for validation. This agrees with the case study reported by [17] which showed the calibration results are better match than validation.

Table 5. Calibration and validation statistic for daily measured and simulated streamflow.

\begin{tabular}{llll}
\hline Parameter & $\begin{array}{l}\text { Calibration } \\
(\mathbf{2 0 0 3 - 2 0 0 9 )}\end{array}$ & $\begin{array}{l}\text { Validation } \\
\mathbf{( 2 0 1 0 - 2 0 1 4 )}\end{array}$ & Remark \\
\hline $\mathrm{R}^{2}$ & 0.73 & 0.68 & Very good \\
$\mathrm{NSE}$ & 0.71 & 0.68 & Very good \\
$\mathrm{P}_{\text {BIAS }}$ & -21.80 & 13.30 & Good \\
\hline
\end{tabular}

Table 6. Comparison of daily measured and simulated flows.

\begin{tabular}{lll}
\hline \multirow{2}{*}{ Period } & Average Flow $\left(\mathbf{m}^{3} / \mathbf{s}\right)$ & \\
\cline { 2 - 3 } & Measured & Simulated \\
\hline Calibrated (2003-2009) & 8.93 & 10.88 \\
Validated (2010-2014) & 10.07 & 8.73 \\
\hline
\end{tabular}

Table 7. Calibration and validation statistic for monthly measured and simulated streamflow.

\begin{tabular}{llll}
\hline Parameter & $\begin{array}{l}\text { Calibration } \\
\mathbf{( 2 0 0 2 - 2 0 0 8 )}\end{array}$ & $\begin{array}{l}\text { Validation (2009- } \\
\text { 2013) }\end{array}$ & Remark \\
\hline $\mathrm{R}^{2}$ & 0.90 & 0.83 & Very good \\
NSE & 0.89 & 0.82 & Very good \\
$\mathrm{P}_{\text {BIAS }}$ & -6.5 & -12.0 & Good \\
\hline
\end{tabular}

Table 8. Comparison of monthly measured and simulated flows.

\begin{tabular}{lll}
\hline \multirow{2}{*}{ Period } & Average Flow $\left(\mathbf{m}^{3} / \mathbf{s}\right)$ & \\
\cline { 2 - 3 } & Measured & Simulated \\
\hline Calibrated (2003-2009) & 8.93 & 9.51 \\
Validated (2010-2014) & 10.07 & 11.28 \\
\hline
\end{tabular}


Figures 7 to 12 are graphical and scatter plot representations of the comparison of observed and simulated streamflow values for both calibration and validation periods at flow monitoring station. The graphical representations show that there is good approach (similar pattern) between observed and simulated flow. The Scatter plot between the observed and simulated data for calibration as well as for validation period has also showed that there is a good agreement between observed and simulated data. However, the graph also reveals there is small difference between the measured and the simulated results. The small difference shows the uncertainty of the model that can be occurred due to: error in measurements of weather variables, conversion from point precipitation into areal measurement and when the model considers the influence of the ground water on the runoffrainfall relationship while the modeler may ignore this factor.

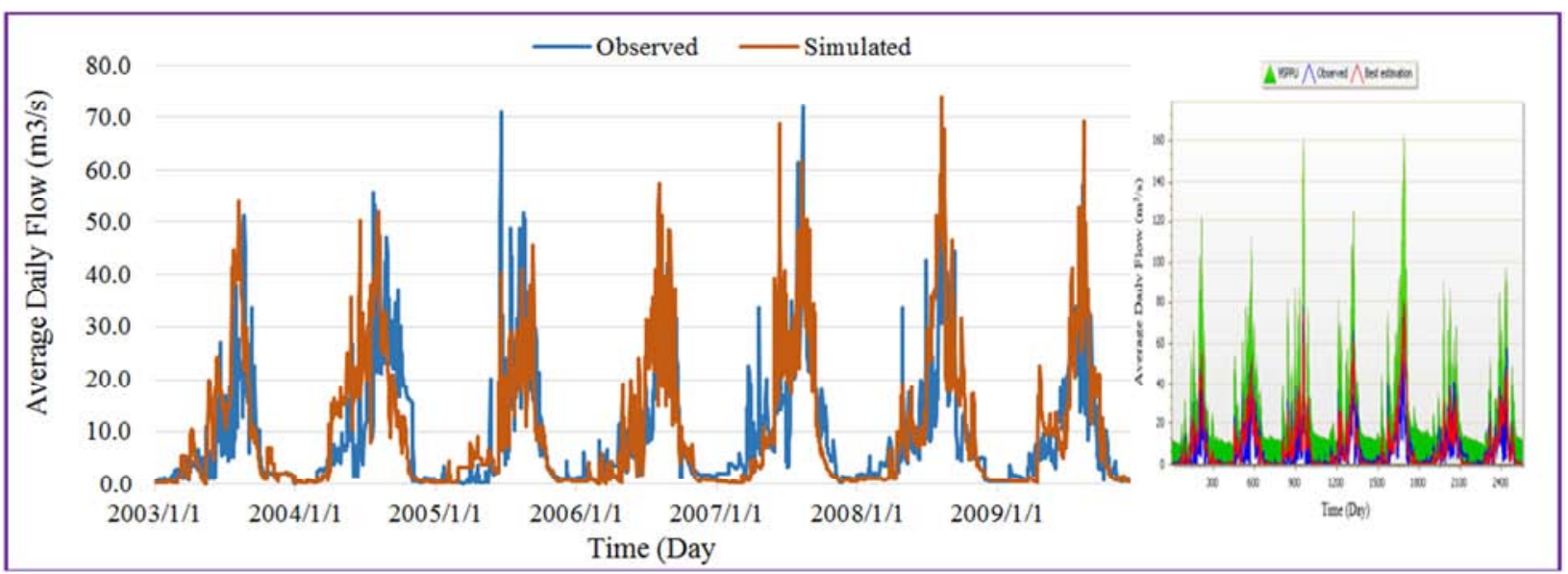

Figure 7. Calibration results of daily measured and simulated flow (2003-2009).

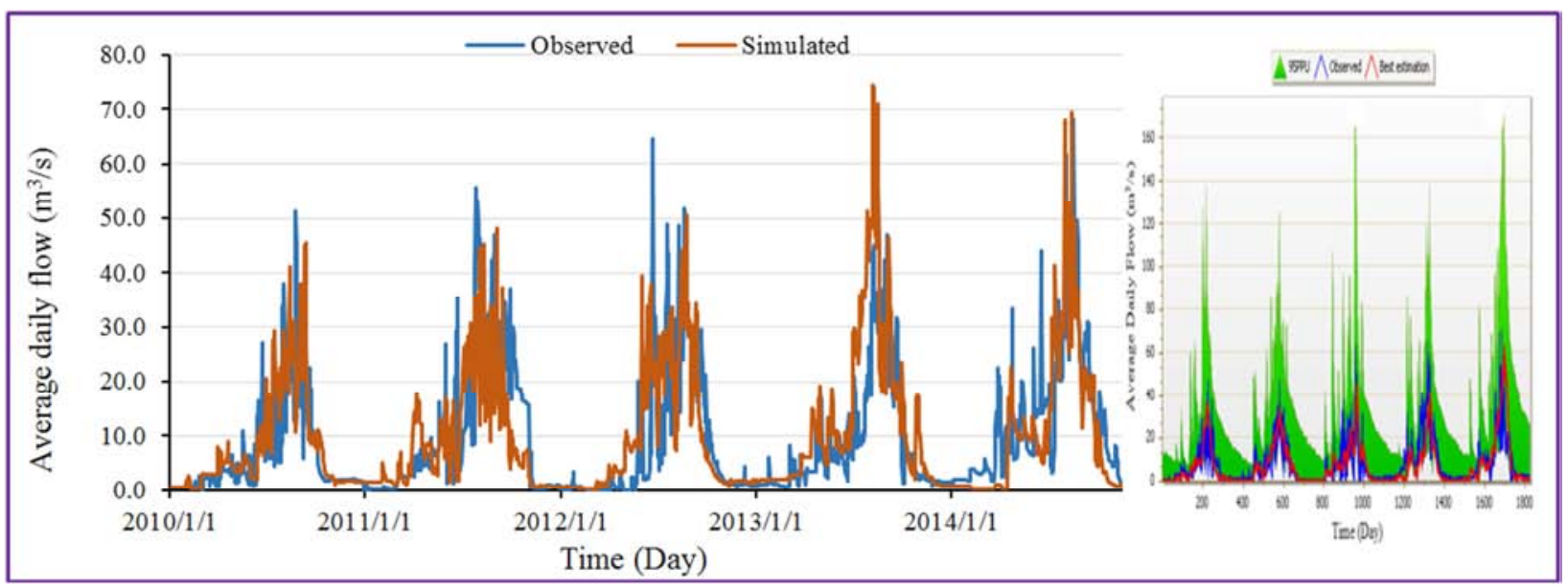

Figure 8. Validation results of daily measured and simulated streamflow (2010-2014).

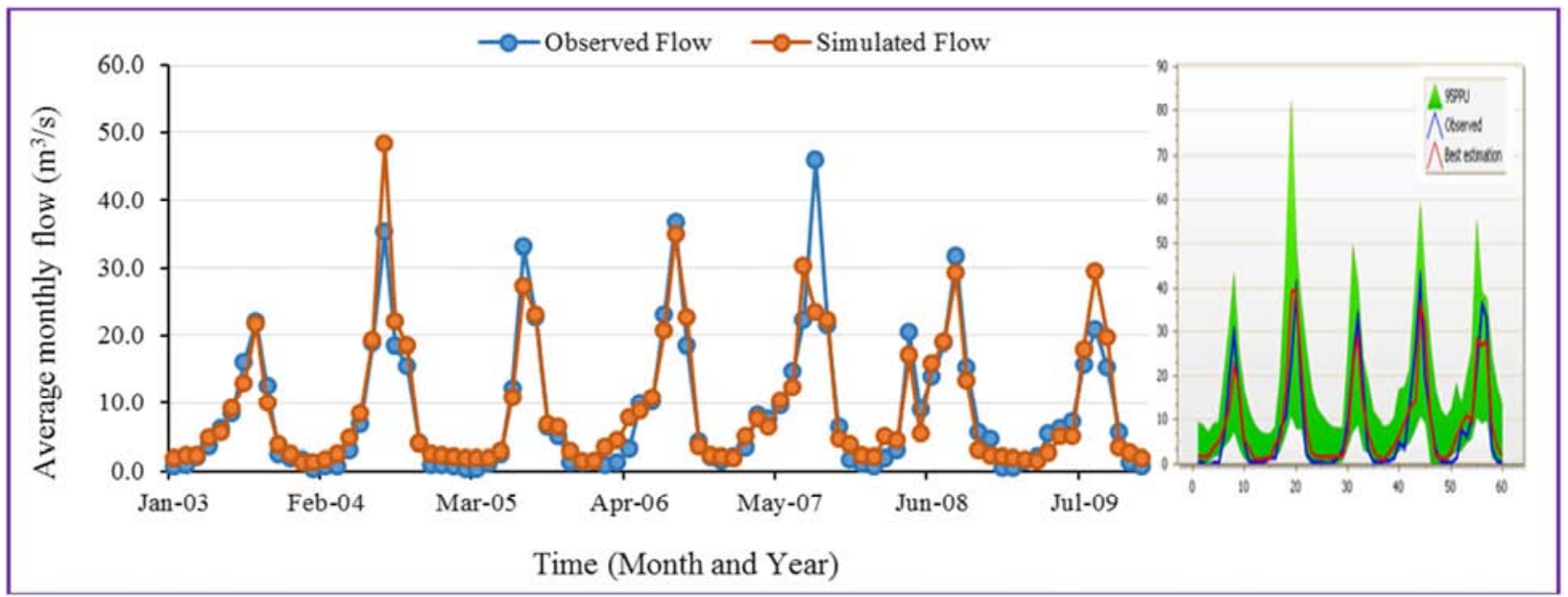

Figure 9. Calibration results of monthly measured and simulated flow (2003-2009). 


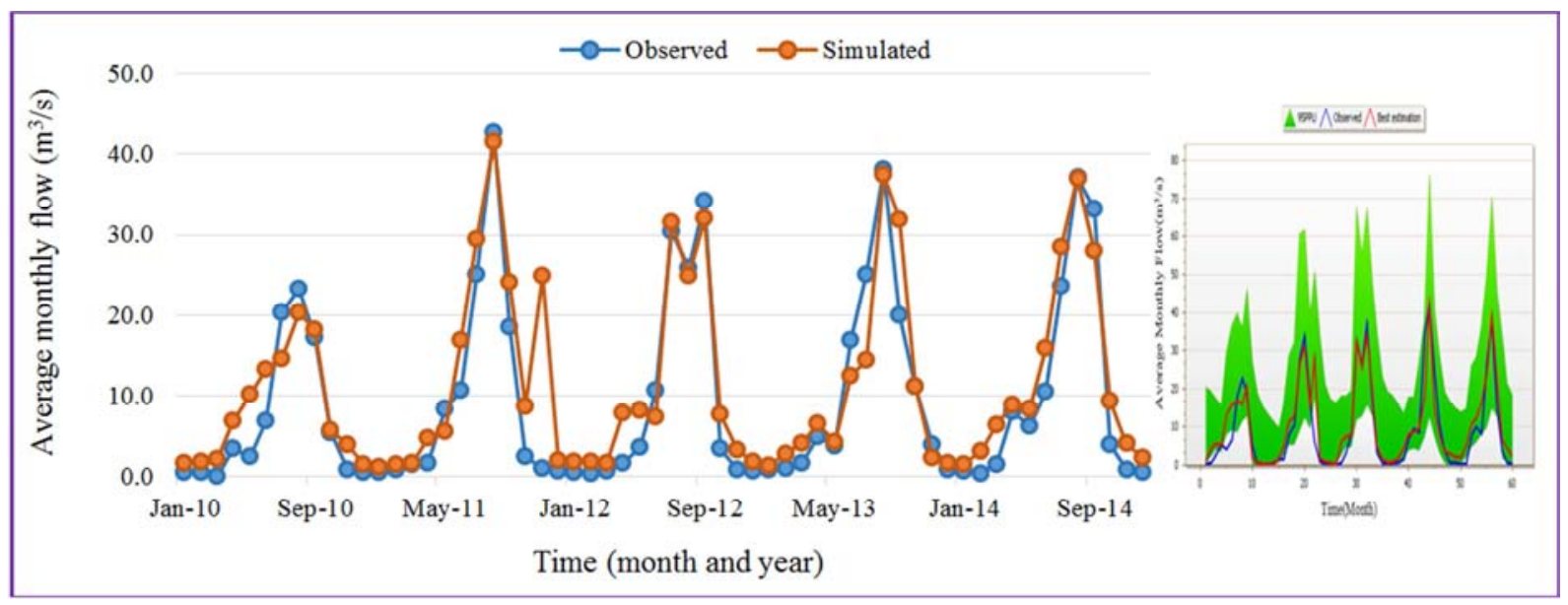

Figure 10. Validation results of monthly measured and simulated flow (2010-2014).
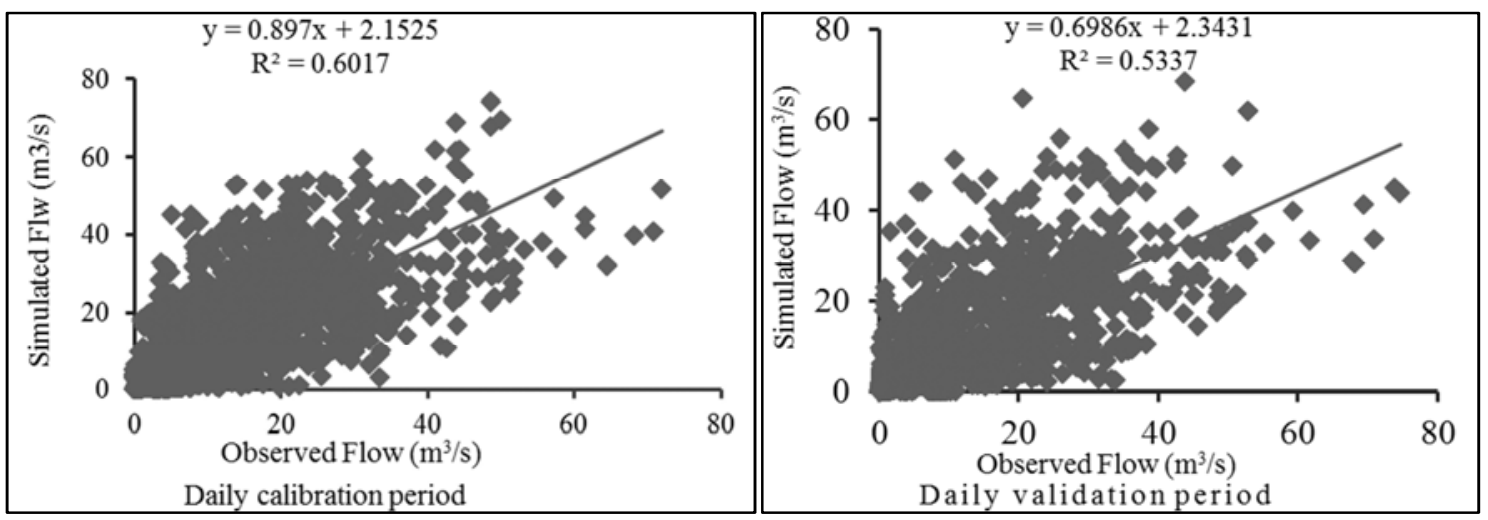

Figure 11. Scatter plot of daily Simulated versus observed flow during calibration and validation.
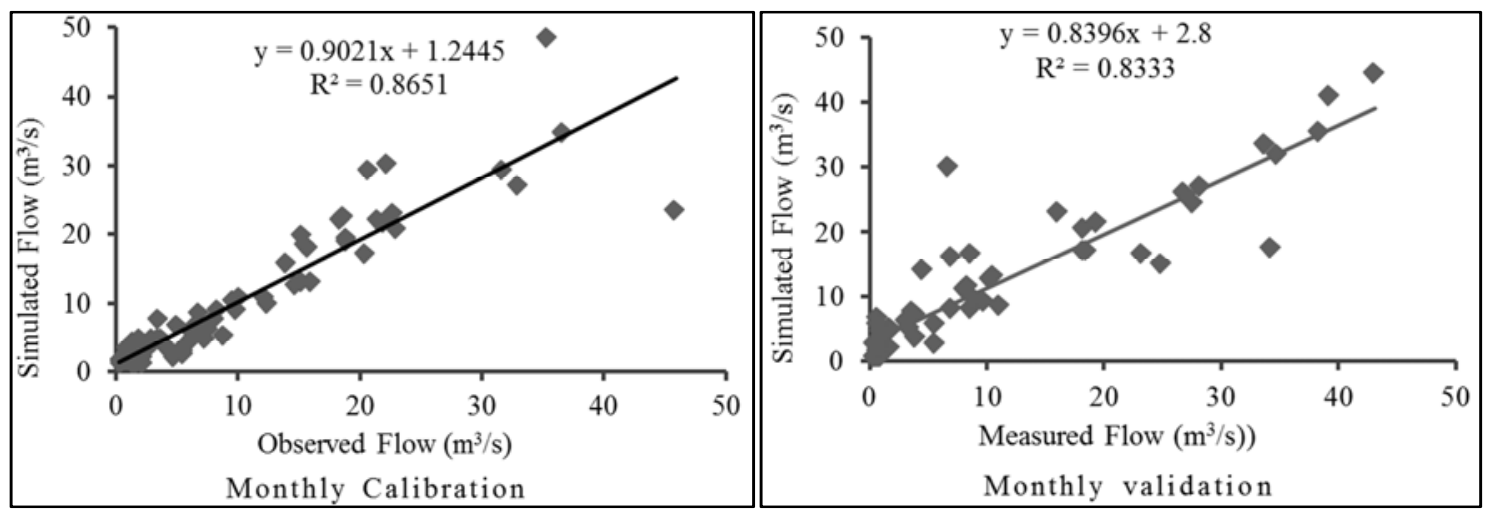

Figure 12. Scatter plot of monthly measured vs simulated flow during validation.

\subsubsection{Sediment Yield Calibration and Validation}

The model was also calibrated for total sediment yield from Meki Watershed by utilizing a monthly time series dataset from 1st January of 2003 to 31st December of 2009. SWAT simulates total sediment load including bed load. It is therefore necessary to include the bed load component on the suspended load to have total sediment load for the model calibration and validation. However, in most studies in Ethiopia, the bedload component is frequently ignored due to measurement constraints. In most rivers, bed load to suspended load ranges from 10 to $30 \%$ [18]. Meki watershed flow on gentle slope to moderately steep slope throughout its course. Hence, bedload were assumed as $15 \%$ of the suspended sediment load computed from the rating curve and summed up to give total sediment load (treated as observed) for model calibration.

For sediment calibration, five sensitive sediment parameters were identified and their values were iterated several times within a reasonable range during calibration until satisfactory agreement between observed and simulated sediment yield was obtained. Those are USLE_P.mgt, USLE_K.mgt, SLSUBBSN.hru, EROS_EXPOO.bsn, CH COV1.rte, CH EQN.rte, SPCON.bsn, SPEXP.bsn and C_FACTOR.bsn (table 9). 
Table 9. Calibration parameters and their fitted values.

\begin{tabular}{lllll}
\hline Parameter Name & $\begin{array}{l}\text { Fitted } \\
\text { Value }\end{array}$ & $\begin{array}{l}\text { Minimum } \\
\text { value }\end{array}$ & $\begin{array}{l}\text { Maximum } \\
\text { value }\end{array}$ & $\begin{array}{l}\text { Method of } \\
\text { variation }\end{array}$ \\
\hline SLSUBBSN.hru & 47.4501 & 10.00000 & 150.0000 & Replacement \\
EROS_EXPO.bsn & 1.51125 & 1.500000 & 3.000000 & Replacement \\
CH_COV1.rte & 0.40013 & -0.05000 & 0.600000 & Replacement \\
SPCON.bsn & 0.00196 & 0.000100 & 0.010000 & Replacement \\
SPEXP.bsn & 1.10625 & 1.000000 & 1.500000 & Replacement \\
C_FACTOR.bsn & 0.19295 & 0.001000 & 0.450000 & Replacement \\
\hline
\end{tabular}

The sediment yield calibration and validation statistical values (table 10) indicated that there is a very good match between observed and simulated sediment yield. The graphical representations of the comparison of observed and simulated sediment yield results for both calibration and validation periods also possess the similar patterns (figures 13 and 14).

Table 10. Calibration and validation statistics for monthly measured and simulated Sediment yield.

\begin{tabular}{llll}
\hline Parameter & Calibrated & Validated & Remark \\
\hline $\mathrm{R}^{2}$ & 0.82 & 0.76 & Very good \\
$\mathrm{N}_{\mathrm{SE}}$ & 0.80 & 0.73 & Very good \\
$\mathrm{P}_{\mathrm{BIAS}}$ & -2.9 & 2.1 & Very good \\
\hline
\end{tabular}

Table 11. Comparison of monthly measured and simulated sediments during calibration and validation.

\begin{tabular}{lll}
\hline \multirow{2}{*}{ Period } & \multicolumn{2}{l}{ Average Sediment Yield (t/month) } \\
\cline { 2 - 3 } & Measured & Simulated \\
\hline Calibrated & 97288.95 & $100,128.18$ \\
Validated & 110530.75 & $108,212.95$ \\
\hline
\end{tabular}

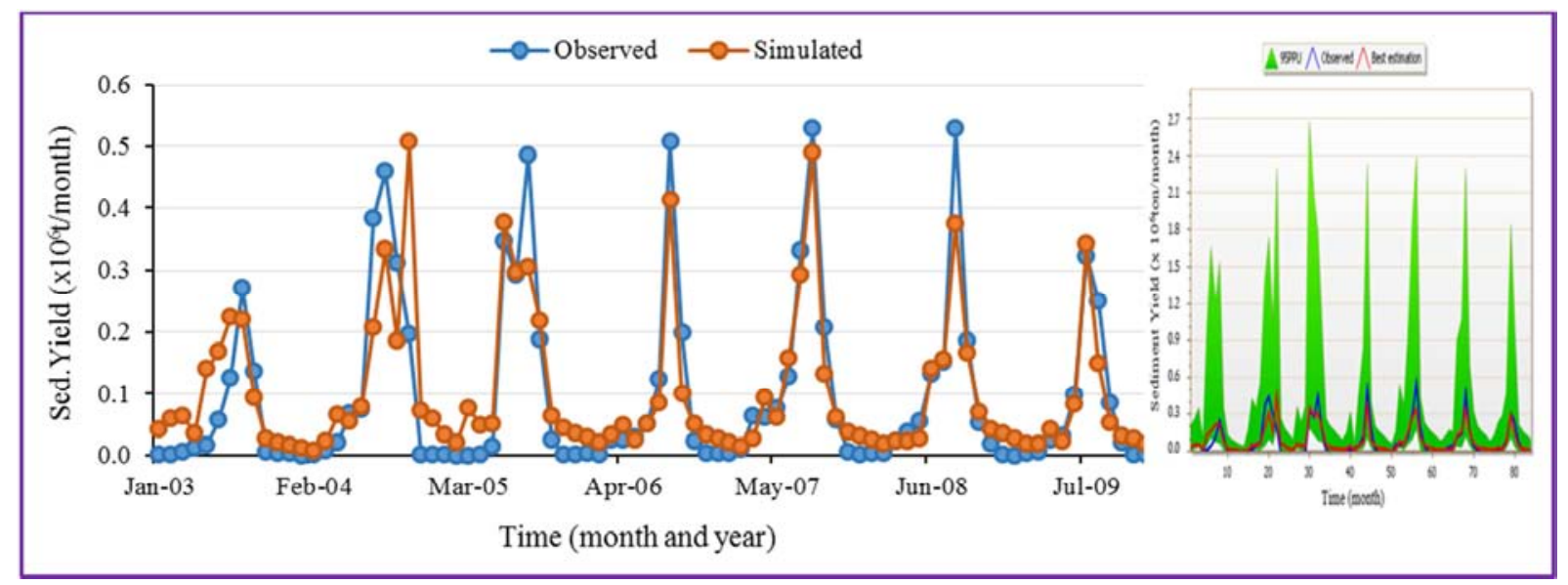

Figure 13. Calibration results of monthly measured and simulated sediment yield.

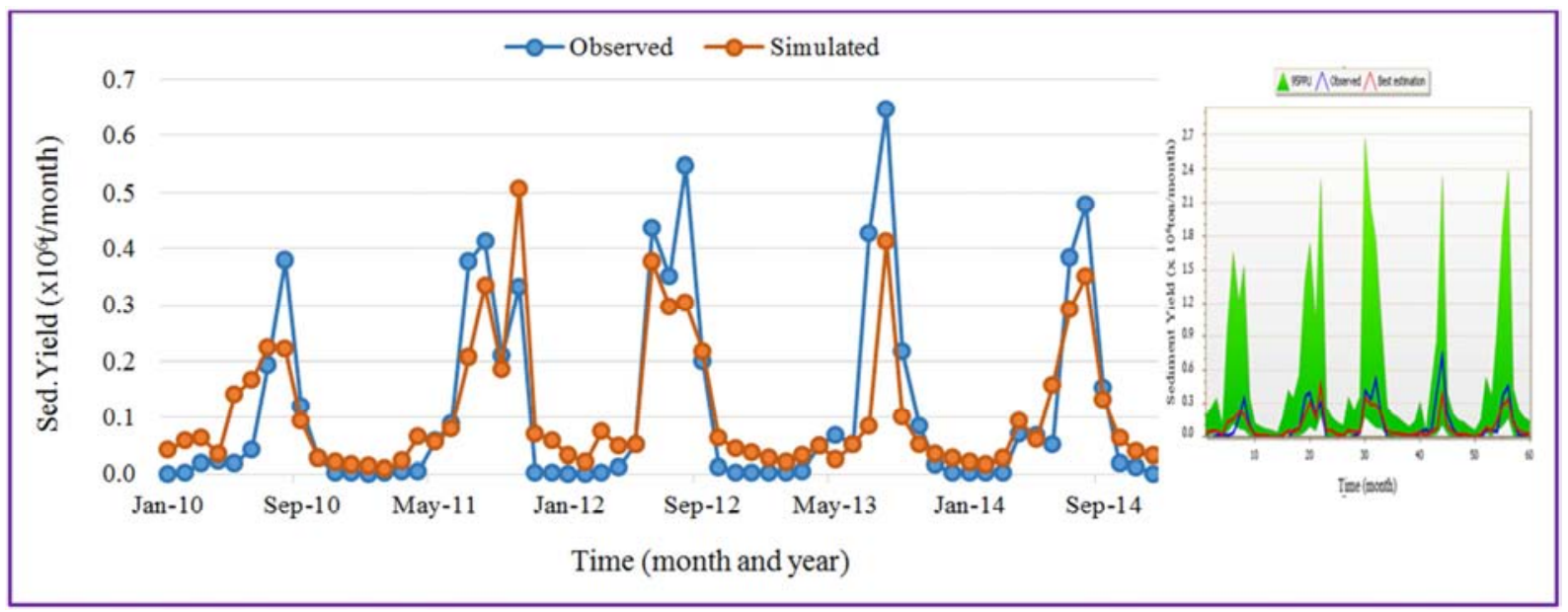

Figure 14. Validation results of monthly measured and simulated flow.

\subsection{Identification of Erosion Prone Sub-watershed}

Implementation of soil conservation measures in the entire basin at a time is difficult specially in developing countries because of resource limitation. Hence, categorization of subwatersheds by erosion severity classes is imperative for immediate intervention.
Different Authors have classified the soil erosion severity into slightly varying classes. [19] classified $0-5$ ton/ha/year as very low, 5-10 ton/ha/year as low, 10-20 ton/ha/year as medium and yield greater than 20 ton/ha/year as high. [20] classified $0-11$ ton/ha/year as low, 11-18 ton/ha/year as medium, 18-30 ton/ha/year as high and yield greater than 30 ton/ha/year as very high. In this study, the spatial distribution of the annual average sediment yield from the seventeen sub- 
basins were classified into four erosion intensity classes (table 12) with a little modification of suggested values in $[19,20]$.

Table 12. Soil erosion intensity classification.

\begin{tabular}{lll}
\hline S.N & Soil erosion (ton $\backslash$ halyear) & Erosion intensity class \\
\hline 1 & $0-5$ & Very low \\
2 & $5-11$ & Low \\
3 & $11-18$ & Medium \\
4 & $>18$ & High \\
\hline
\end{tabular}

In Ethiopia, the soil loss class that can maintain the economy and a high level of production ranges from 0 to 11 ton/ha/year [20]. Hence, for design and implementation of appropriate conservation measures to reduce the onsite and offsite impact of soil erosion in the watershed, six main erosion source areas with annual average sediment yield greater than 11 ton/ha/year were prioritized. Likewise, sub- basins 1, 2, 4, 12, 15 and 16 were identified as the areas considerably prone to soil erosion problem and they need effective control measurement in the watershed. The maximum upland sediment yield was 35.52 metric ton per ha of the watershed produced from sub-basin 15, landuse: AGRL, soil: Fibric Histosols, whereas the minimum annual sediment yield was 0.34 ton/ha/yr and it was from sub-basin 10 .

The amounts of sediment eroded from each sub watersheds are found to be primarily influenced by the topography and soil type than the existing surface runoff for the study area. Soil erosion severity in the areas of higher altitudes with longer and steeper slope as well as in the areas dominated by soil types such as Fibric Histosols, Vertic Cambisols and Eutric Vertisols is found to be more sever. High steeper slope cause increased runoff velocity, and with this, the kinetic energy of water causes more erosion.

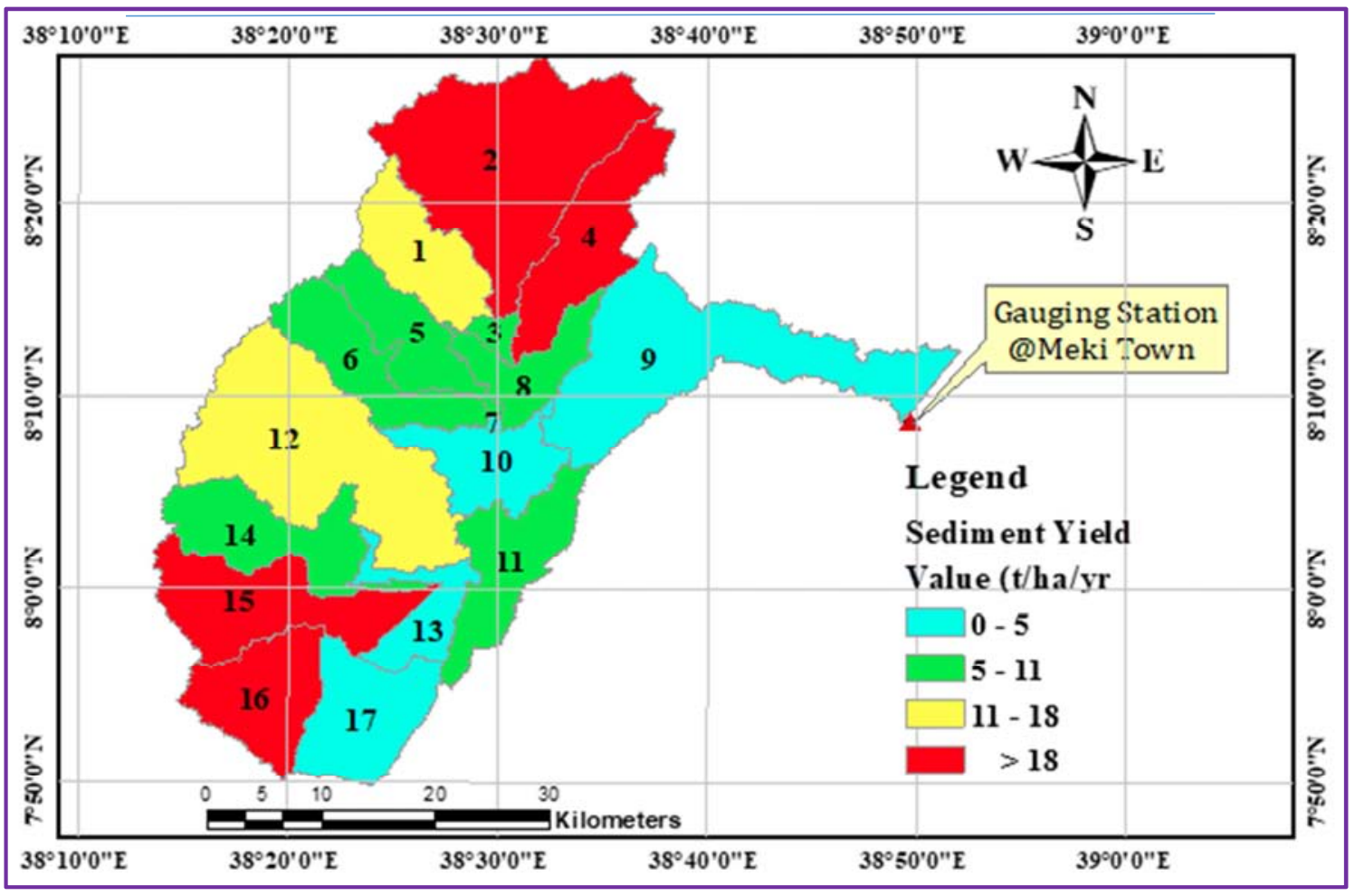

Figure 15. Spatial Distribution of annual sediment yield classes of Meki Watershed.

\section{Conclusion}

This study was conducted to characterize the Meki River watershed in terms of spatial distribution of sediment yield in order to prioritize the sub-basin areas which need watershed management by using current SWAT model version 2012. The model performance was evaluated using Standard calibration and validation statistics. A very good agreement between measured and simulated monthly streamflow and sediment yield was obtained. The model over estimated simulated flow by $6.5 \%$ and $12.0 \%$ in both calibration and validation periods respectively yield in Meki River watershed. A good performance of the model in the Validation period indicates that the fitted parameters during calibration period can be taken as a representative set of parameters for Meki watershed. After model calibration and validation, hot spot erosion areas were identified and priorized for implementation Management Practices (MPs) to reduce the onsite and offsite impact of soil erosion in the watershed. From assessment of sediments spatial distribution, 51.34\% of the Meki watershed hilly and escarpment areas are found to be the potential sources of erosion. Overall, SWAT model performed well in simulating runoff and sediment yield on daily and monthly basis at the watershed scale and thus can be used as a planning tool for watershed management and can bridge the gap of adequate information between processes at the micro watershed and large watershed level. 
To apply appropriate conservation mechanism in reducing the severe erosion, there is a need of further study to evaluate the impact of different types of land management practices on water, sediment, and agricultural chemical yields in watershed. For instant, it is proposed to cover the identified potential erosion sources with vegetation to deescalate further degradation by erosion.

\section{Acknowledgements}

We would like to sincerely acknowledge National Meteorology Agency (NMA) and Ministry of Water, Mineral and Electricity (MoWME) of Ethiopia for providing data needed for the study. We are also thankful to Addis Ababa Science and Technology University and Wollega University for their support in all facilities up to the end.

\section{References}

[1] Pasquale Borrelli, David A. Robinson, Panos Panagos, Emanuele Lugato, Jae E. Yang, Christine Alewell, David Wuepper, Luca Montanarella, and Cristiano Ballabio, (2020): Land use and climate change impacts on global soil erosion by water (2015-2070). PNAS |September 8, 2020| vol. 117| no. $36 \mid 21995$.

[2] Gonfa Erena, Dereje Adeba. (2020): Modeling Sediment Yield-Case Study Guder Watershed, Blue Nile Basin, Central Ethiopia. American Journal of Civil Engineering. Vol. 9, No. 2, 2021, pp. 39-46. doi: 10.11648/j.ajce.20210902.12. (Cross reference).

[3] Lulseged Tamene. D. (2005). Reservoir siltation in Ethiopia: Causes, source areas, and management options. Ecology and Development Series No. 30.

[4] Temesgen Gashaw, Taffa Tulu and Mekuria Argaw, (2017): Erosion risk assessment for prioritization of conservation measures in Geleda watershed, Blue Nile basin, Ethiopia. Environ Syst Res (2017) 6: 1 DOI 10.1186/s40068-016-0078x.

[5] Setegn, Srinivasan R, and Dargahi B, 2008 The Open Hydrology Journal 2 49-62 Singh V P and Woolhiser D A 2002 Journal of Hydrologic Engineering 7 (4) 270-292.

[6] Betrie, G. B., Y. A. Mohammed, A. Van Griensven, and Srinivasan. (2011). Sediment yield modeling in the Blue Nile Basin using the SWAT model. Hydro. Earth science, 15, 807- 818.

[7] Clarke, R. T. 1994. Statistical Modeling in Hydrology, 412 p.
[8] Neitsch SL, Arnold JG, Kiniry JR, Williams JR., 2005 Soil and Water Assessment Tool, Theoretical Documentation: Version 2005. Temple, TX. USDA Agricultural Research Service and Texas A \& M Black land Research Centre.

[9] Arnold, J. G, Moriasi, D. N, Gassman, P. W, Abbaspour, K. C, White, M. J, Srinivasan, R, et al. (2012). SWAT: Model Use, Calibration and Validation, American Society of Agricultural and Biological Engineers, Vol. 55 (4): 1491-1508.

[10] USDA Soil Conservation Service, 1972 National Engineering Handbook Section 4 Hydrology, Chapters 4-10, 1972.

[11] Huffman, R., Fangmeier, D., Elliot, W., Workman, S., \& Schwab, G.: Infiltration and Runoff. Soil and Water Conservation Engineering, 81-111, 2011.

[12] Wischmeier, W. H., and Smith, D. D.: "Predicting Rainfall Erosion Losses." Agriculture Handbook No. 537, USDA, Science and Education Administration, US Govt., Washington, DC, 1978).

[13] Abbaspour, K. C. (2014). SWAT-CUP 2012: SWAT Calibration and Uncertainty Programs-A User Manual.

[14] Krause, D. P. Boyle, and F. Base, (2005). Comparison of different efficiency criteria for hydrological model assessment Labrière, N.; Locatelli, B.; Laumonier, Y.; Freycon, V.; Bernoux, M. Soil erosion in the humid tropics: A systematic quantitative review. Agric. Ecosyst. Environ. 2015, 203, 127 139.

[15] Gupta, H. V., S. Sorooshian, and P. O. Yapo. 1999. Status of automatic calibration for hydrologic models: Comparison with multilevel expert calibration. J. Hydrologic Eng. 4 (2): 135143.

[16] Abbaspour, K., Johnson, A., and Genuchten. M. Th. (2007). Estimating Uncertain flow and transport parameters using a sequential uncertainty fitting procedure. Vadose Zone Journal 3 (4), $1340-1352$.

[17] Damtew Fufa, (2015) Swat Based Hydrological Modelling of Katar Watershed, Lake Ziway Catchment, Ethiopia.

[18] Church, M. Bed material transport and the morphology of Alluvial River Channels. Annu. Rev. Earth Planet. Sci. 2006, 34, 325-354.

[19] Singh G, Babu R, Narayan P, et al. (1992) Soil erosion rates in India [J]. Journal of Soil and Water Conservation, 47: 97-99.

[20] Dulo Husen, Brook Abate. Estimation of Runoff and Sediment Yield Using SWAT Model: The Case of Katar watershed, Rift Valley Lake Basin of Ethiopia. International Journal of Mechanical Engineering and Applications. Vol. 8, No. 6, 2020, pp. 125-134. doi: 10.11648/j.ijmea.20200806.11. 